\title{
SENSORY ASPECTS AND REDUCTION OF Salmonella IN IRRADIATED EGG POWDER
}

\author{
Aspectos sensoriais e redução de Salmonella de ovo em pó irradiado
}

\author{
Ângela Froehlich ${ }^{1}$, Bernadette Dora Gombossy de Melo Franco², \\ Maria Teresa Destro ${ }^{2}$, Mariza Landgraf ${ }^{2}$
}

\begin{abstract}
Eggs and their products have been implicated in food-borne disease outbreaks due to contamination with Salmonella Enteritidis. Irradiation, as a food preservation technology, could minimize such contamination. The aim of this study was to determine the effects of irradiation in powdered egg yolk, egg white, and whole egg samples spiked with Salmonella Enteritidis. The powdered egg samples were exposed to doses of $0.5,1.0,1.0,2.0,2.5,3.0,3.5$, or $4.0 \mathrm{kGy}$ irradiation. Odors and tastes of raw and cooked non-inoculated, irradiated samples, and non-irradiated samples, were analyzed by a trained panel. A dose of $2.0 \mathrm{kGy}$ resulted in slight to moderate changes in powdered egg yolk samples, compared to non-irradiated controls, while minimal differences were observed in powdered egg white samples. The dose of $3.5 \mathrm{kGy}$, when applied to samples of powdered egg white, resulted in taste and odor slightly stronger than the non-irradiated control. The maximum irradiation threshold before changes in flavor and odor occurred was $2.28 \mathrm{kGy}$, for powdered yolk and whole eggs, and $2.58 \mathrm{kGy}$, for powdered egg white. Those thresholds were enough to reduce $S$. Enteritidis to safe levels.
\end{abstract}

Index terms: Bacteria; elimination; powder food.

\begin{abstract}
RESUMO
Os ovos e os seus produtos derivados têm sido implicados em doenças de origem alimentar devido à contaminação com Salmonella Enteritidis. A irradiação é um método tecnológico de preservação de alimentos que pode minimizar esse tipo de contaminação. O objetivo do presente estudo foi determinar os efeitos da irradiação nas amostras de gema de ovo em pó, clara de ovo em pó e ovo integral em pó contaminadas artificialmente com Salmonella Enteritidis. As amostras de ovo em pó foram expostas a doses de $0,5,1,0,1$,5, 2,0, 2,5, 3,0, 3,5 ou 4,0 kGy de irradiação. As amostras não contaminadas irradiadas e não irradiadas foram avaliadas por um painel de especialistas que avaliaram odor e sabor cru e cozido não inoculados, amostras irradiadas e não irradiadas. A dose de 2,0 kGy resultou em alterações leves a moderadas nas amostras de gema de ovo em pó em comparação aos controles não-irradiados, enquanto diferenças mínimas foram observados em amostras de ovo em pó. A dose de 3,5 kGy quando aplicada às amostras de clara de ovo em pó resultou em sabor e odor mais fortes do que no controle não irradiado. O limite máximo da dose de radiação sem causar alteração significativa no sabor e odor foi 2,28 kGy para gema em pó e ovos inteiros e 2,58 kGy para clara em pó e suficiente para reduzir $S$. Enteritidis para níveis seguros.
\end{abstract}

Termos para indexação: Bactéria; eliminação; alimento em pó.

\section{INTRODUCTION}

Each year, the poultry industry produces millions of eggs in fresh, frozen, and dehydrated forms. In addition to their high nutritional value, eggs are one of the most affordable sources of animal protein; and because of their functional properties, they are an ingredient in myriad food products.

In the food industry, pasteurized, frozen, or dehydrated eggs are preferred to shelled eggs because of comparable taste, color, nutritional value, and functional properties; and they provide superior quality, increased stability, and uniformity. Furthermore, frozen or dehydrated eggs are more economical to handle, require reduced storage space, and are easily portioned (Anonimous, 1998).

Of the microorganisms found in eggs and their derivatives, Salmonella genus merits attention due to the number of outbreaks it causes because of the consumption of undercooked eggs (Patrick et al., 2004).

Although Salmonella cannot actively multiply in water below 0.92, Salmonella can survive for long periods in eggs (D'Aoust; Maurer; Bailey, 2001). The survival of $S$. Enteritidis in powdered eggs has been observed in $35 \%$ of samples analyzed in the United States, $10 \%$ of those analyzed in Great Britain, and $55 \%$ of Canadian samples (International Commission on Microbiological Specifications for Foods, 1996). Radkowski (2002),

\footnotetext{
1Instituto Federal de Alagoas/IFAL - Câmpus Satuba - Rua 17 de Agosto - s/n - 57120-000 - Satuba - AL - Brasil - angela.ifal@gmail.com

2Universidade de São Paulo/USP - Faculdade de Ciências Farmacêuticas - São Paulo - SP - Brasil

Received in january 23, 2015 and approved in july 20, 2015
}

Ciênc. Agrotec., Lavras, v. 39, n. 5, p. 506-513, set./out., 2015 
observed that, depending on hygiene and available technology, contamination of Polish samples ranged from 9.9 to $55 \%$.

Salmonellosis is a disease caused by $S$. Enteritidis, transmitted in food, which emerged mainly during the 1980s. In 1976, the incidence of $S$. Enteritidis was 0.55 per 100,000 people representing only $5 \%$ of all isolates, in 1985 this ratio reached 2.4 per 100,000 (Patrick et al. 2004), representing $10 \%$ of all known isolates.

Tavechio et al. (1996), reported a significant increase from 1993 of the isolation of $S$. Enteritidis in clinical samples in Brazil. According to Silva and Duarte (2002), this increase is due to the import of contaminated poultry and the expanded production of the Brazilian poultry industry.

In an attempt to reduce problems arising from contamination by microorganisms, whole eggs, egg whites, and egg yolks are subjected to pasteurization or pasteurization followed by dehydration. In developing countries, 14 to $30 \%$ of eggs are converted into pasteurized liquid or dried egg products (Dias; Ajzental; Calil, 2002).

Although dehydration during the production of egg powder reduces contamination, some microorganisms can survive and may develop in favorable conditions of the food product to which the egg is added (Dóka; Kispéter; Bicanic, 1997).

Due to the possible survival of contaminants, including Salmonella in eggs, studies of conservation methods, that increase the microbiological safety and product shelf life, are warranted. Irradiation is a possible method to reduce Salmonella to safe levels.

Irradiation is attractive for heat-sensitive products such as eggs. While considerably reducing the transmission of food-borne infectious diseases, such as salmonellosis, the temperature is not increased and changes in aroma, flavor, color, and nutrition are minimized (Radomysky et al., 1994). This process is used in some countries to treat frozen, liquid, powdered, and shell eggs (International Atomic Energy Agency-IAEA, 1998; Hyun et al., 2010; RODRIGUES et al., 2011; and MIN et al., 2012), but some aspects remain to be studied.

The objectives of this research were to determine radio resistance of Salmonella Enteritidis in spiked, powdered egg yolk, egg white, and whole egg samples, and evaluate the feasibility of this process by sensory analysis.

\section{MATERIAL AND METHODS}

\section{Sensory analysis}

Samples (50 g) of powdered egg yolk, egg white, or whole egg were stored in polyethylene. Samples were kept at room temperature until irradiation, and were exposed to doses of $0.5,1.0,1.5,2.0,2.5,3.0,3.5$, or $4.0 \mathrm{kGy}$.

Following irradiation, samples and non-irradiated controls were analyzed by the Descriptive and Quantitative Analysis (DQA) (Stone; Siedes, 1985). This evaluation considered the smell and flavor of raw and cooked egg products.

The trained panelists evaluated the odor and flavor of irradiated and non-irradiated products using the following scale:

(9) Significantly stronger than the standard

(8) Much stronger than the standard

(7) Moderately stronger than the standard

(6) Slightly stronger than the standard

(5) Equal to the standard

(4) Slightly weaker than the standard

(3) Moderately weaker than the standard

(2) Much weaker than the standard

(1) Significantly weaker than the standard

To assess the taste of the product, samples were reconstituted with water (one part egg in three parts water) containing salt and were cooked for two minutes in a microwave oven.

The results of each attribute, from each taster, were statistically evaluated with Analysis of Variance (ANOVA), and averages were compared with Dunnett's test, both at $5 \%$ probability.

The parameters L (luminosity), a (red +, green -), and $\mathrm{b}$ (blue + , yellow -), all of which are related to color, were determined with a Minolta spectrophotometer (model CM. 5 089, Japan).

\section{Inoculation and irradiation of samples}

A pool was prepared containing three strains of $S$. Enteritidis $(S$. Enteritidis ATCC 13070, $S$. Enteritidis isolated from raw eggs, and $S$. Enteritidis isolated from raw meat) in trypticase soy broth, with $0.6 \%$ yeast extract (TSBYE), and it was incubated at $37^{\circ} \mathrm{C}$ for 24 hours. Then, $1 \mathrm{~mL}$ of culture $\left(10^{9}\right.$ to $\left.10^{10} \mathrm{CFU} \mathrm{mL} \mathrm{mL}^{-1}\right)$ was added to $99 \mathrm{~g}$ of powdered egg yolk, egg white, or whole egg for a final concentration of $10^{7}$ to $10^{8} \mathrm{CFU} \mathrm{g}^{-1}$, homogenized with a sterile glass rod. After homogenization, the samples were divided in 25-g aliquots in polyethylene packets and stored at room temperature until irradiation. The irradiation doses were the same as for the sensory analysis.

After irradiation, $25 \mathrm{~g}$ of the product were homogenized in $225 \mathrm{~mL}$ of TSBYE for 30 seconds using a Stomacher piston homogenizer (Seward, London, UK), and incubated at $37{ }^{\circ} \mathrm{C}$ for one hour to allow injured cells to recover (Ray, 1989). Successive decimal dilutions were 
made in $0.85 \% \mathrm{NaCl}$. Three successive dilutions were cultured in duplicate in TSAYE and incubated at $37^{\circ} \mathrm{C}$ for 48 hours. Three colonies from each plate were subjected to EPM, milli and citrate (Enterokit B, Probac), testing and subsequently confirmed by agglutination with polyvalent serum for Salmonella, (Probac of Brasil, São Paulo, BR). The number of bacteria was reported as CFU/g.

\section{RESULTS AND DISCUSSION}

\section{Sensory analysis}

The cooked odor and taste of the powdered egg yolk were slightly to moderately less favorable in samples exposed to doses above $2.0 \mathrm{kGy}$ or $1.5 \mathrm{kGy}$, respectively (Table 1).

Irradiation caused the odor and taste to differ in powdered yolk samples exposed to $0.5 \mathrm{kGy}$. The odor change of irradiated raw yolk varied from slightly to moderately stronger than the control. The change in odor and taste of the cooked yolk was slightly and moderately weaker, respectively, in samples exposed to doses above $2.0 \mathrm{kGy}$ (cooked odor) or above $1.5 \mathrm{kGy}$ (cooked flavor) (Table 1).

The odor of irradiated, uncooked, powdered egg white samples changed minimally, varying from slightly weaker to moderately stronger than the control (Table 2), and the odor and taste of cooked egg whites had similar results.

The odor of raw powdered whole egg samples was moderately stronger at a dose of $2.5 \mathrm{kGy}$. Both the odor and taste of cooked whole eggs had minimal changes and were evaluated as slightly stronger at doses equal to and above $3.5 \mathrm{kGy}$ (Table 3).
These results are similar to those of Katusin-Razem et al., (1989); changes in sensory attributes were not observed for whole egg powder exposed to $2.4 \mathrm{kGy}$ in the presence of oxygen. However, even without oxygen, the product remained unchanged when exposed to $5.0 \mathrm{kGy}$. The presence of oxygen encourages the production of free radicals, which are responsible for reactions that change the taste and odor of irradiated foods.

The yolk was the most sensitive egg product to irradiation. This result can be explained by the chemical composition of the yolk. The higher lipid content in the yolk, compared to the egg white, caused changes in taste of the irradiated, cooked product. Cooked egg white exposed to $2.5 \mathrm{kGy}$ did not differ significantly in taste compared to the control (Table 2), though the difference between the yolk samples and the control were statistically significant (Table 1).

Ijichi et al. (1964) and Grim and Goldblith (1965), reported changes in taste of irradiated whole eggs. MA et al. (1993), detected a change in the odor of irradiated frozen yolks, which intensified with increasing doses of irradiation, though a change was not observed in frozen egg whites. This was explained by modification of yolk lipoproteins, which are more sensitive to radiation than proteins in the egg white.

Differences were not observed in the luminosity of powdered yolk samples, but the red and yellow decreased at doses of 2.0 and $2.5 \mathrm{kGy}$, respectively (Table 4). MA et al. (1993), Huang, Herald an Mueller (1997), Ferreira and Del Mastro (1998), and Du and Ahn (2000), observed similar changes in irradiated powdered yolk.

Table 1: Evaluation of raw flavor, cooked flavor, and cooked taste of powdered yolk exposed to different doses of gamma radiation.

\begin{tabular}{cccc}
\hline Dose $(\mathrm{kGy})$ & Raw odor & Cooked odor & Cooked Taste \\
\hline 0.0 & $5.00 \mathrm{bc} \mathrm{c}^{*}$ & $5.00 \mathrm{bac}$ & $5.00 \mathrm{ba}$ \\
0.5 & $6.00 \mathrm{a}$ & $5.62 \mathrm{a}$ & $5.62 \mathrm{a}$ \\
1.0 & $5.62 \mathrm{ba}$ & $5.62 \mathrm{a}$ & $6.37 \mathrm{a}$ \\
1.5 & $6.00 \mathrm{a}$ & $5.25 \mathrm{ba}$ & $4.37 \mathrm{bc}$ \\
2.0 & $5.37 \mathrm{bc}$ & $4.62 \mathrm{bc}$ & $4.00 \mathrm{dc}$ \\
2.5 & $4.62 \mathrm{~d}$ & $4.37 \mathrm{c}$ & $3.37 \mathrm{~d}$ \\
3.0 & $5.62 \mathrm{ba}$ & $4.37 \mathrm{c}$ & $3.37 \mathrm{~d}$ \\
\hline
\end{tabular}

(9) significantly stronger than the standard; (8) much stronger than the standard; (7) moderately stronger than the standard; (6) slightly stronger than the standard; (5) equal to the standard; (4) slightly weaker than the standard; (3) moderately weaker than the standard; (2) much weaker than the standard; (1) significantly weaker than the standard.

* Different letters in the same column mean that there was a significant difference compared to the control sample (Dunnett's test at 5\% probability).

Ciênc. Agrotec., Lavras, v. 39, n. 5, p. 506-513, set./out., 2015 
Table 2: Evaluation of raw odor, cooked odor, and cooked flavor of powdered egg whites exposed to different doses of gamma radiation.

\begin{tabular}{cccc}
\hline Dose $(\mathrm{kGy})$ & Raw odor & Cooked odor & Cooked taste \\
\hline 0.0 & $5.00 \mathrm{dc}^{*}$ & $5.00 \mathrm{cb}$ & $5.00 \mathrm{cb}$ \\
0.5 & $4.50 \mathrm{~d}$ & $4.25 \mathrm{~cd}$ & $4.25 \mathrm{~cd}$ \\
1.0 & $5.50 \mathrm{bc}$ & $5.00 \mathrm{cb}$ & $5.00 \mathrm{cb}$ \\
1.5 & $5.12 \mathrm{dc}$ & $4.00 \mathrm{~d}$ & $4.00 \mathrm{~d}$ \\
2.0 & $5.63 \mathrm{bac}$ & $4.25 \mathrm{~cd}$ & $4.25 \mathrm{~cd}$ \\
2.5 & $6.25 \mathrm{a}$ & $5.25 \mathrm{~b}$ & $5.25 \mathrm{~b}$ \\
3.0 & $6.00 \mathrm{ba}$ & $6.50 \mathrm{a}$ & $6.50 \mathrm{a}$ \\
\hline
\end{tabular}

(9) significantly stronger than the standard; (8) much stronger than the standard; (7) moderately stronger than standard; (6) slightly stronger than the standard; (5) equal to the standard; (4) slightly weaker than the standard; (3) moderately weaker than the standard; (2) much weaker than the standard; (1) significantly weaker than the standard.

* Different letters in the same column mean that there was a significant difference compared to the control sample (Dunnett's test at $5 \%$ probability).

Table 3: Evaluation of the raw odor, cooked odor, and cooked taste of powdered whole egg exposed to different doses of gamma radiation.

\begin{tabular}{cccc}
\hline Dose $(\mathrm{kGy})$ & Raw odor & Cooked odor & Cooked taste \\
\hline 0.0 & $5.00 \mathrm{c}^{*}$ & $5.00 \mathrm{~b}$ & $5.00 \mathrm{c}$ \\
0.5 & $5.75 \mathrm{~b}$ & $5.00 \mathrm{~b}$ & $5.00 \mathrm{c}$ \\
1.0 & $6.00 \mathrm{~b}$ & $5.12 \mathrm{~b}$ & $5.00 \mathrm{c}$ \\
1.5 & $6.00 \mathrm{~b}$ & $5.75 \mathrm{a}$ & $5.25 \mathrm{cb}$ \\
2.0 & $6.00 \mathrm{~b}$ & $5.75 \mathrm{a}$ & $5.50 \mathrm{~b}$ \\
2.5 & $7.00 \mathrm{a}$ & $5.50 \mathrm{ba}$ & $5.50 \mathrm{~b}$ \\
3.0 & $7.00 \mathrm{a}$ & $5.75 \mathrm{a}$ & $5.00 \mathrm{c}$ \\
3.5 & $6.75 \mathrm{a}$ & $6.00 \mathrm{a}$ & $6.00 \mathrm{a}$ \\
4.0 & $7.00 \mathrm{a}$ & $6.00 \mathrm{a}$ & $6.00 \mathrm{a}$ \\
\hline
\end{tabular}

(9) significantly stronger than the standard; (8) much stronger than the standard; (7) moderately stronger than standard; (6) slightly stronger than the standard; (5) equal to the standard; (4) slightly weaker than the standard; (3) moderately weaker than the standard; (2) much weaker than the standard; (1) significantly weaker than the standard.

* Different letters in the same column mean that there was a significant difference compared to the control sample (Dunnett's test at $5 \%$ probability).

The parameters "L" and "b" did not change in irradiated powdered egg white. The parameter "a" had negative values, suggesting a green color. This is because egg whites have no carotene, which provides the red color of the yolk (Table 5). For irradiated powdered whole egg samples, a difference compared to the non-irradiated control was only observed in the parameter " $b$ " when treated with $3.0 \mathrm{kGy}$ (Table 6).
Powdered whole egg was more stable in color when irradiated due to the lower concentration of carotenoids compared with powdered yolk.

Color changes of powdered yolk and whole eggs are likely caused by the degradation of carotenoids, which increases with the radiation dose. Katusin-Razem, Mihaljivic and Razem (1992), observed a reduction of $49 \%$ of the carotenoids in powdered whole egg when treated with $9.0 \mathrm{kGy}$, and an even greater reduction in powdered yolks. 
Table 4: Average of "L", "a" and "b" values for powdered yolk samples exposed to different doses of gamma radiation.

\begin{tabular}{cccc}
\hline Dose $(\mathrm{kGy})$ & "L" & "a" & "b" \\
\hline 0.0 & $86.38 \mathrm{a} *$ & $6.01 \mathrm{a}$ & $40.49 \mathrm{a}$ \\
0.5 & $86.23 \mathrm{a}$ & $6.18 \mathrm{a}$ & $39.35 \mathrm{a}$ \\
1.0 & $85.83 \mathrm{a}$ & $5.97 \mathrm{a}$ & $38.89 \mathrm{ba}$ \\
1.5 & $85.71 \mathrm{a}$ & $5.79 \mathrm{a}$ & $37.54 \mathrm{bac}$ \\
2.0 & $85.30 \mathrm{a}$ & $4.20 \mathrm{cb}$ & $35.04 \mathrm{bac}$ \\
2.5 & $85.28 \mathrm{a}$ & $3.33 \mathrm{cb}$ & $30.84 \mathrm{bdc}$ \\
3.0 & $85.06 \mathrm{a}$ & $3.22 \mathrm{cb}$ & $30.05 \mathrm{dc}$ \\
\hline
\end{tabular}

"L" represents the luminosity: a higher value indicates a clearer sample; "a" refers to the colors red (+) and green (-); "b" represents the colors yellow $(+)$ and blue $(-)$.

*Different letters in the same column mean that there was difference compared to the control (Dunnett's test at $5 \%$ probability).

Table 5: Average "L", "a" and "b" values for powdered egg white samples exposed to different doses of gamma radiation.

\begin{tabular}{cccc}
\hline Dose (kGy) & "L" & "a" & "b" \\
\hline 0.0 & $92.82 \mathrm{a} *$ & $-0.69 \mathrm{a}$ & $16.17 \mathrm{a}$ \\
0.5 & $94.04 \mathrm{a}$ & $-0.75 \mathrm{a}$ & $16.34 \mathrm{a}$ \\
1.0 & $92.79 \mathrm{a}$ & $-0.76 \mathrm{a}$ & $16.40 \mathrm{a}$ \\
1.5 & $94.16 \mathrm{a}$ & $-0.77 \mathrm{a}$ & $16.78 \mathrm{a}$ \\
2.0 & $93.68 \mathrm{a}$ & $-1.03 \mathrm{~b}$ & $16.24 \mathrm{a}$ \\
2.5 & $93.74 \mathrm{a}$ & $-0.77 \mathrm{a}$ & $17.03 \mathrm{a}$ \\
3.0 & $92.52 \mathrm{a}$ & $-0.66 \mathrm{a}$ & $16.92 \mathrm{a}$ \\
\hline
\end{tabular}

"L" represents the luminosity: a higher value indicates a clearer sample; "a" refers to the colors red (+) and green (-); "b" represents the colors yellow (+) and blue (-).

*Different letters in the same column mean that there was difference compared to the control (Dunnett's test at 5\% probability).

Table 6: Average values of "L", "a" and "b" for powdered whole egg samples exposed to different doses of gamma radiation.

\begin{tabular}{cccc}
\hline Dose (kGy) & "L" & "a" & "b" \\
\hline 0.0 & $87.75 \mathrm{a} *$ & $4.73 \mathrm{a}$ & $23.06 \mathrm{bdc}$ \\
0.5 & $87.60 \mathrm{a}$ & $4.67 \mathrm{ba}$ & $22.81 \mathrm{dc}$ \\
1.0 & $87.67 \mathrm{a}$ & $4.39 \mathrm{ba}$ & $22.63 \mathrm{dc}$ \\
1.5 & $87.43 \mathrm{a}$ & $4.48 \mathrm{ba}$ & $22.46 \mathrm{~d}$ \\
2.0 & $87.26 \mathrm{a}$ & $4.31 \mathrm{ba}$ & $22.80 \mathrm{dc}$ \\
2.5 & $86.44 \mathrm{a}$ & $4.74 \mathrm{a}$ & $23.79 \mathrm{ba}$ \\
3.0 & $86.39 \mathrm{a}$ & $4.72 \mathrm{a}$ & $24.00 \mathrm{a}$ \\
3.5 & $86.41 \mathrm{a}$ & $4.73 \mathrm{a}$ & $24.21 \mathrm{a}$ \\
4.0 & $8.27 \mathrm{a}$ & $4.25 \mathrm{~b}$ & $23.46 \mathrm{bac}$ \\
\hline
\end{tabular}

"L" represents the luminosity: a higher value indicates a clearer sample; "a" refers to the colors red (+) and green (-); "b" represents the colors yellow (+) and blue (-).

*Different letters in the same column mean that there was difference compared to the control (Dunnett's test at 5\% probability).

Ciênc. Agrotec., Lavras, v. 39, n. 5, p. 506-513, set./out., 2015 


\section{Reduction of the population of $S$. Enteritidis by gamma radiation}

A maximum dose of $4.0 \mathrm{kGy}$ resulted in a reduction of $5.7 \log$ cycles in the $S$. Enteritidis population (Figure 1) in powdered egg yolks.

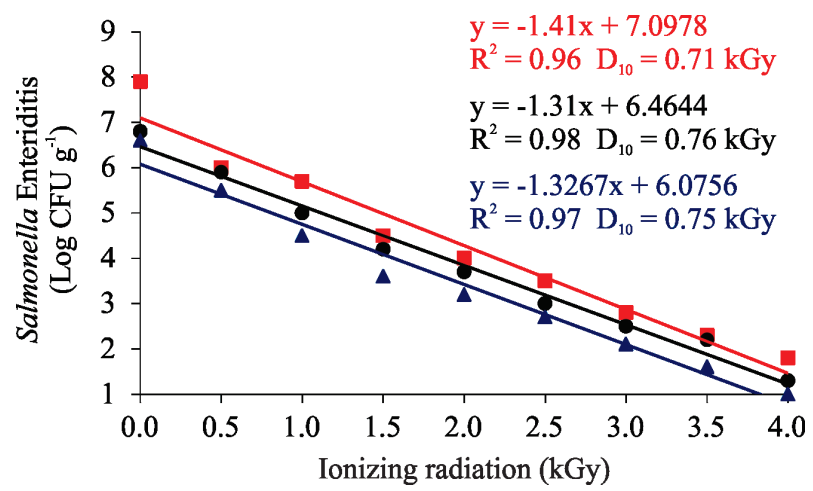

Figure 1: Behavior of Salmonella Enteritidis inoculated in powdered yolk samples, subjected to gamma radiation with doses of $0.0 ; 0.5 ; 1.0 ; 1.5 ; 2.0 ; 2.5 ; 3.0 ; 3.5$ and 4.0 kGy (three replicates).

The values of decimal reduction doses for powdered yolk varied from 0.71 to $0.76 \mathrm{kGy}$ (Figure 1 ), this may be due to the lower water content of the yolk powder.

Powdered egg white samples treated with $3.0 \mathrm{kGy}$ had a reduction of $3.8 \log$ cycles (Figure 2), lower than observed for the powdered yolk (Figure 1). This suggests interference of the chemical composition of the product with the effectiveness.

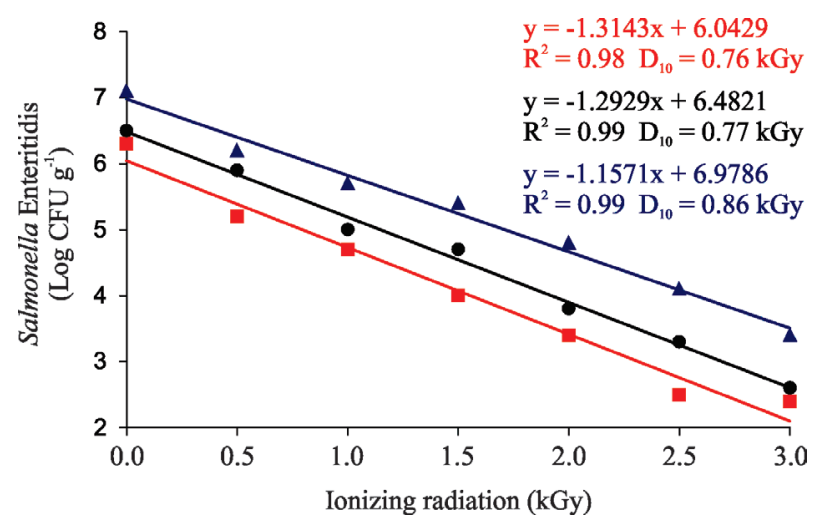

Figure 2: Behavior of Salmonella Enteritidis inoculated in egg white powder samples, subjected to gamma radiation with doses of $0.0 ; 0.5 ; 1.0 ; 1.5 ; 2.0$; 2.5 and $3.0 \mathrm{kGy}$ (three replicates).
The $\mathrm{D}_{10}$ values for $S$. Enteritidis of the powdered egg white samples varied from 0.76 to $0.86 \mathrm{kGy}$ (Figure 2), similar to the values observed for powdered yolk. This similarity may result from the chemical composition of these substances. While the yolk has a high lipid content, which interferes with the effects of radiation on microorganisms, egg whites have a high protein content, which can also protect the microbes.

A dose of $2.0 \mathrm{kGy}$ resulted in a reduction of 3 $\log$ cycles in the $S$. Enteritidis population (Figure 3 ) in powdered whole egg samples, which is in agreement with Bomar (apud Farkas, 1998), and Katusin-Razem et al. (1989), who observed that similar doses had the same effects without altering the sensory characteristics of the product.

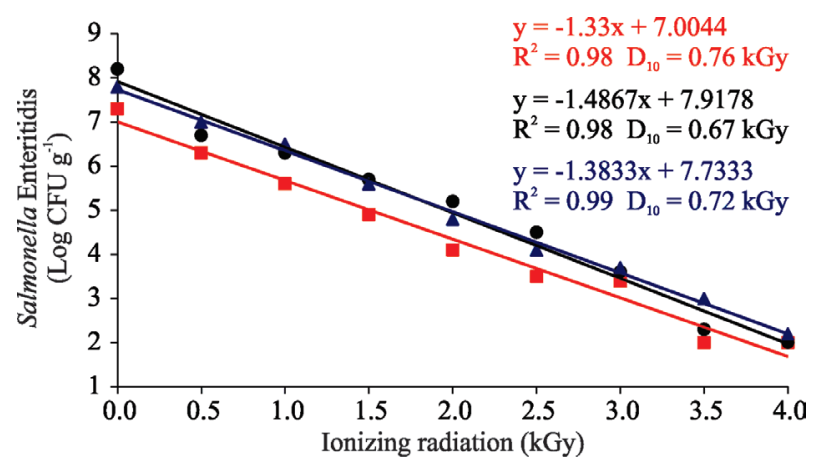

Figure 3: Behavior of Salmonella Enteritidis inoculated in powdered whole egg samples subjected to gamma radiation at doses of $0.0 ; 0.5 ; 1.0 ; 1.5 ; 2.0 ; 2.5 ; 3.0 ; 3.5$ and $4.0 \mathrm{kGy}$ (three replicates).

The dose decimal reduction for $S$. Enteritidis inoculated in powdered whole eggs varied from 0.67 to $0.76 \mathrm{kGy}$ (Figure 3), similar to those found for yolk powder.

The results obtained for powdered yolk, egg white, and whole eggs differed from the findings of Thornley (apud Farkas, 1998), which indicated that irradiated powdered whole eggs inoculated with Salmonella had $\mathrm{D}_{10}$ values of $0.60 \mathrm{kGy}$, lower than the result in our study. Results of Kohler, Hubner et al. and Krautschick et al. (1989), for $S$. Agonna and $S$. Tennessee, were 0.95 and $1.07 \mathrm{kGy}$, respectively, for the same product, those values are greater than what was observed in our study.

According to Humphrey et al. (1989), Salmonella

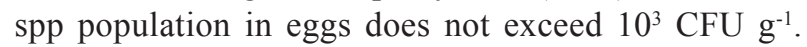
Therefore, the dose needed to reduce the population 
to undetectable levels is $2.28 \mathrm{kGy}$ for powdered yolk and whole eggs, and $2.58 \mathrm{kGy}$ for powdered egg white. However, the product's tolerated dose is $4.0 \mathrm{kGy}$, under which the untrained consumer is likely unable to detect the slight to moderate sensory attribute differences.

\section{CONCLUSIONS}

A dose of $2.0 \mathrm{kGy}$ resulted in flavor and light to moderate odor changes of egg yolk in powdered samples, compared to the non-irradiated control, as minimum differences were observed in powdered egg samples. Egg yolk powder was the most sensitive product to the process studied due to the presence of large amounts of lipids. To eliminate contamination with $S$. Enteritidis in egg powder, egg yolk powder, and egg white powder, we recommend a maximum dose of $2.28 \mathrm{kGy}$, to ensure the safety of these products without changing significantly their sensory characteristics. The changes as determined by a panel of experts were slightly or moderately stronger or weaker. These would likely be unnoticed by the consumer, as egg products are frequently used as ingredients in other foods.

\section{REFERENCES}

ANONIMOUS. Folder - Egg - The Dream Ingredient! Food Technology. 52, 1998.

D'AOUST, J.; MAURER, J. BAILEY, J.S. Salmonella species. In: DOYLE, M.P., BEUCHAT, L.R., MONTEVILLE, T.J. (Eds.) Food Microbiology: Fundamentals and Frontiers. Washington, ASM, 2001. p.141-178.

DIAS, A.P.; AJZENTAL, A.; CALIL, R.M. Avaliação da microbiota pré e pós-pasteurização do ovo líquido. Higiene Alimentar. 16(100):127-133, 2002.

DÓKA, O.; KISPÉTER, J.; BICANIC, D. The photoacoustic assessment of ${ }^{60} \mathrm{C}$ irradiation induced effects in egg powders: results in the UV and visible. Instrumentation Science Technology. 25(4):297-306, 1997.

DU, M.; AHN, D.U. Effects of antioxidants and packaging on lipid and cholesterol oxidation and colors changes of irradiated egg yolk powder. Journal of Food Science. 65(4):625-629, 2000.

FARKAS, J. Irradiation as a method for decontaminating food. A review. International Journal of Food Microbiology. 44:189-204, 1998.
FERREIRA, L.F.S.; DEL MASTRO, N. Rheological changes in irradiated chicken eggs. Radiatyon Physics Chemistry. 52:59-62, 1998.

GRIM, A.C.; GOLDBLITH, S.A. The effect of ionizing radiation on the flavor of whole-egg magma. Food Technology. 10:138-140, 1965.

HUANG, S.; HERALD, T.J.; MUELLER, D.D. Effect of beam irradiation on physicochemical, and functional properties of liquid egg yolk during frozen storage. Poultry Science. 76(11):1607-1615, 1997.

HUMPHREY, T.J. et al. Salmonella Enteritidis PT4 from the contents of intact eggs: a study involving naturally infeted hens. Epidemiology and Infection. 103:415-423, 1989.

HYUN, J.K. et al. Effects of electron beam irradiation on pathogen inactivation, quality and functional properties of shell egg during ambient storage. Korean Journal for Food Science of Animal Resources. 30(4):603-608, 2010.

INTERNATIONAL ATOMIC ENERGY AGENCY IAEA. Food Environmental Protection Newsletter. 1:1-17, 1998.

INTERNATIONAL COMMISSION ON MICROBIOLOGICAL SPECIFICATIONS FOR FOODS. Microbial ecology of foods. In: Eggs and Eggs Products. Academic Press. New York, 1996, v.2, p.564.

IJICHI, K. et al. Effects of ultraviolet irradiation of egg liquids on Salmonella destruction and performance quality with emphasis on egg White. Food Technology. 10:1628-1632, 1964.

KATUSIN-RAZEM, B.; MIHALJIVIC, B.; RAZEM, D. Radiation-induced oxidative chemical changes in dehydrated egg products. Journal of Agricultural and Food Chemistry. 40:662-668, 1992.

KATUSIN-RAZEM, B. et al. Chemical and organoleptic properties of irradiated dried whole egg and egg yolk.

Journal of Food Protection. 52(11):781, 1989.

KLINE, L. et al. Heat pasteurization of raw liquid egg White. Food Technology. 19(105):1709, 1965. 
KOHLER, B.; HUBNER, H.; KRAUTSCHICK, M. The use of ionizing radiation for the decontamination of salmonella-containing slaughtered broiler chickens and powdered eggs. Zeitschrift für die Gesamte Hygiene und Ihre Grenzgebiete. 35(11):665-668, 1989.

MA, C.Y. Effects of gamma irradiation on physicochemical and functional properties of eggs and egg products. Radiation Physics Chemistry. 48(3):375, 1993.

MIN, B. et al. Irradiation of shell egg on the physicochemical and functional properties of liquid egg white. Poultry Science. 91(10):2649-2657, 2012.

PATRICK, M.E. et al. Salmonella Enteritidis, infections, United States, 1985-1999. Emerging Infectious Diseases. 10(1):1-7, 2004.

RADKOWSKI, M. Survival of Salmonella spp. in whole powdered egg. Archives für Lebensmittel Hygiene. 53(3):60-61, 2002.

RADOMYSKI, T. et al. Elimination of pathogens of significance in food by low-dose irradiation: a review. Journal of Food Protection. 57(1):73-86, 1994.
RAY, B. Enumeration of injured indicator bacteria from foods. In: Injured Index and Pathogenic Bacteria: Occurrence and Detection in Foods, Water and Feeds, Florida: CRC Press, 1989. p.954.

RODRIGUES, E.C.P. et al. Effects of gamma irradiation on the viability and phenotypic characteristics of Salmonella Enteritidis inoculated into specific-pathogenfree eggs. Journal of Food Protection. 12(8):20312038, 2011.

SILVA, E.N.; DUARTE, A. Salmonella Enteritidis em aves: retrospectiva no Brasil. Revista Brasileira de Ciência Avícola. 4(2):85-100, 2002.

STONE, H.; SIDEL, J. L. Descriptive analysis. In: STONE, H.; SIDEL, J.L. (Eds.) Sensory Evaluation Practices. London: Academic Press, 1985. 311p.

TAVECHIO, A.T. et al. Changing patterns of Salmonella serovars: increase of Salmonella Enteritidis in São Paulo, Brazil. Revista Instituto de Medicina Tropical de São Paulo. 38(5):315-322, 1996. 